\title{
The Impact of Love of Money, Gender and Social Economic Status on Ethical Perceptions of UNDIKSHA Accounting Students
}

\author{
Ni Komang Deasy Darmayanti ${ }^{1}$ Ni Putu Ayu Yuli Sumadianti $1{ }^{1, *}$ Dewa Gede \\ Kumara Dana ${ }^{2}$ Ida Ayu Kade Pradnyawati ${ }^{1}$ Ayun Pramesti Woro Hapsari ${ }^{1}$ Luh Putu \\ Malina Dewi ${ }^{1}$ \\ ${ }^{1}$ Department of Economics and Accounting, Universitas Pendidikan Ganesha, Singaraja, Indonesia \\ ${ }^{2}$ Department of Management, Universitas Pendidikan Ganesha, Singaraja, Indonesia \\ *Corresponding author. Email: ayu.yuli@undiksha.ac.id
}

\begin{abstract}
Accountants are professions whose existence is enormously structured on public trust, as an accountant in carrying out their duties need to uphold their ethics. This locate out about was once carried out to determine the affect of love of money, gender and socioeconomic fame on ethical perceptions of UNDIKSHA accounting undergraduate students. This examine about makes use of quantitative methods. The populace used is the 2017 classification of college students majoring in economics \& accounting, accounting learn about program. The sampling strategy in this analyze about used comfort sampling by the use of a pattern of 195 students. The facts supply used is most important data. The records used to be once received from distributing questionnaires through google shape to respondents. The results confirmed that; (1) Love of money has a poor impact on moral perceptions of accounting students, (2) gender has an impact on moral perceptions of accounting students, and (3) socioeconomic reputation has a terrible affect on moral perceptions of accounting college students.
\end{abstract}

Keywords: Gender and social economic status, Ethical perception, Love of money.

\section{INTRODUCTION}

Individuals and groups must share values in order for community life to thrive. These ethical norms can help to minimize conflict and the presence of disadvantaged parties inside the organization. Ethics is a moral attitude that has to do with making judgments about what is and is not acceptable behaviour. Ethical wants are felt when one's ethical values differ from those of others. As a result, humans require ethics in order to determine what should be done.

Ethics is a moral attitude that has to do with making judgments about what is and is not acceptable behaviour. Ethical wants are felt when one's ethical values differ from those of others. As a result, humans require ethics in order to determine what should be done. Perception is a person's perspective on a situation or problem that incorporates prior information. Ethics is concerned with one's behaviour toward others [1].
Perception is the lens thru which an accounting student views himself or herself as a prospective accountant after gaining day trip and mastering about accounting ethics from an accountant.

Ethics is required to regulate future behaviour, as is the case in the accounting profession. Due to the increasing level of competition, the accounting profession is frequently under pressure to maintain strong ethical standards. Accounting is a profession that requires employees to adhere to a code of ethics in order to retain their integrity and confidence in ethical behaviour. The accounting profession places a premium on ethics, as it is inextricably linked to financial. The number of ethical infractions committed by accountants and public accountants continues to rise.

The importance of public trust in the accounting profession is critical in the business sector because if there is an accounting scandal in its business practices, 
it will damage the accounting profession's good name, which may result in negative public opinion. Opinions and impressions about the scandal have a detrimental effect on accounting students who aspire to be accountants, and some of these perceptions can be used to inform future job choices for accounting students. Thus, through ethical perception, we can ascertain how accounting students perceive accounting infractions, with the goal of presenting an overview to all potential accountants of the professionalism required of an accountant who operates on the basis of public confidence.

Ethics has developed into a significant topic that has garnered attention in both the academic and professional worlds. Numerous scenarios arise that include ethical concerns. For instance, consider the corruption issue involving the Indonesian Ministry of Religion and the management of hajj revenues. Corruption in the management of hajj funding is estimated to have cost the state budget Rp 27.283 billion between 2013 and 2014. Surya Dharma Ali is the suspect in this case. He was designated by the Corruption Eradication Commission (KPK) on May 22, 2014. Surya Darma Ali was found to have abused his position as minister of religion between 2010 and 2013. This was an unexpected declaration, given that the Ministry of Religion is a clean and holy institution dedicated to enforcing moral standards in state and religious life. (Nasional.kompas.com). The occurrence of such examples has a detrimental effect on prospective accountants, particularly accounting students. The occurrence of ethical transgressions demonstrates the significance of sensitivity or understanding the accounting profession's ethical responsibilities (Nasional.kompas.com).

Because ethical behaviour is defined as behaviour that adheres to established standards, regulations, procedures, and principles, efforts must be made to reestablish public confidence in the accounting profession. This is inextricably linked to the realm of education, where the accountant acquires know-how and skills in accounting science. Thus, not only specific abilities and knowledge are required in a professional sector, but also an ethical mindset. Ethical theory provides a framework within which we can determine if a moral decision is correct or incorrect [2].

Student behaviour must be studied to determine whether or not they will behave ethically in the future. Mastracchio [3] underlines the need of ethics in accounting school and prior to entering the accounting profession. The manner of turning into a pupil is quite influential, and it is the best moment to develop their personality and personality, as they will be required to make all choices as soon as they enter the world of work. The lookup objectives of this locate out about are as follows: (1) To verify the effect of cash on accounting students' ethical perceptions. (2) To verify the influence of gender on accounting students' moral judgments. (3) To confirm the affect of socioeconomic position on accounting students' moral judgments. Numerous factors influence ethical perceptions, including a desire for money, gender, and social background. The expectation theory and the Theory of Planned Behavior (TPB) both support this.

Accounting students will undoubtedly understand more about financial theory as it relates to money. Someone who has a strong need for money can have a low ethical perception, raising the possibility that they would make unethical decisions while performing their work. This is consistent with studies conducted by Lestari [4] and Diana [5], which found that money has a detrimental effect on accounting students' ethical perceptions, while Aprianti [6] and Saputri [7] found that money had a beneficial effect on accounting students. Accounting students' ethical perceptions The researcher formed the following hypothesis based on the description:

$\mathrm{H}_{1}$ : Affection for money has a negative influence on accounting students' moral judgments

Gender is another issue that determines accounting students' ethical perceptions. Sari, Zuhdi, and Herawati [8] define gender as a feature associated with women and men who are culturally and socially formed. Women have a stronger belief in ethics than males do.

This is consistent with research undertaken by Aprianti [6], which placed that gender had a truly beneficial impact on accounting students' moral perceptions, but Purnamaningsih and Ariyanto [9] located that gender has no impact on accounting students' moral perceptions. The researcher shaped the $2 \mathrm{~d}$ speculation based totally on this description:

$\mathrm{H}_{2}$ : Gender has an impact on accounting students' ethical perceptions.

Socioeconomic status is another aspect that determines accounting students' ethical perceptions. According to Sipayung [10], socioeconomic status refers to a person's perspective or measure of his or her position in terms of social and economic factors such as occupation, income, and participation in a social group. If an individual has a high social position, he or she is more likely to desire more money and engage in consumptive behavior. This relates to ethical behavior, since those with a high socioeconomic level are more likely to act unethically.

Heru [11] conducted study on the effect of socioeconomic status on ethical perceptions; his findings indicate that socioeconomic position has an effect on accounting students' ethical perspectives. This finding contradicts the findings of Purnamaningsih and Ariyanto [9], who found that socioeconomic position 
has a negative effect on accounting students' ethical judgments. The researcher formed the third hypothesis based on this description:

$\mathrm{H}_{3}$ : Socioeconomic position has a negative impact on accounting students' ethical judgments

\section{METHOD}

The research was performed using a quantitative approach. The study's independent elements are love for money, gender, and socioeconomic position, whilst the study's based variable is moral perception. The instrument to be used is determined via these variables. The facts gathering method utilized was a questionnaire issued with the aid of google shape to responders. A Likert scale and a nominal scale are employed to decide the size. The Department of Economics and Accounting, Undergraduate Program, Faculty of Economics, Ganesha Singaraja University of Education is the area of this research. The information used is foremost records in the structure of questionnaire responses. The demographic for this study was students who had been engaged throughout the last semester of the 2017 Accounting Study Program concentrating in Accounting Economics at Ganesha University of Education's Faculty of Economics, which enrolled 380 students. The pattern size for this find out about was once 195 respondents. Convenience sampling was utilized as the retrieval approach. According to Sugiyono [12], convenience sampling is a technique for randomly choosing respondents, such as everybody who meets a researcher and matches the foremost criteria of being an undergraduate pupil of Accounting in the remaining semester of the Ganesha University of Education.

The data evaluation method used in this study is a couple of linear regression analysis, which includes checking out information first-rate measures such as validity and reliability, as well as classical assumption tests such as normality, multicollinearity, and heteroscedasticity, observed by means of hypothesis trying out the use of more than one linear regression analysis, coefficient of willpower tests, and t tests.

\section{RESULTS \& DISCUSSION}

The number of questionnaires distributed equals the range of questionnaires returned. All questionnaires obtained by way of the google form had been complete and accurate, permitting for the processing of all questionnaires, which totaled 195 questionnaires or $100 \%$. The questionnaire consists of 15 items, five of which pertain to the variable moral judgments of accounting students $(\mathrm{Y})$, ten of which pertain to the variable love of cash (X 1), and two of which pertain to the respondent's gender ( $\mathrm{X} 2$ ) and socioeconomic position (X 3).
The 195 respondents in this learn about were categorised according to their gender, age, and monthly income. Respondent characteristics through gender, with sixty four male respondents $(32.8 \%)$ and 131 woman responses $(67.2 \%)$. According to the respondents' ages, there are 0 persons under the age of 21,22 human beings between the ages of 21 and 22, 122 people between the a while of 22 and 22, 122 humans between the a long time of 22 and 22, forty eight human beings between the ages of 23 and 24, and 3 human beings over the age of 23 . (1.5\%). Additionally, it suggests that respondents with a month-to-month profits of extra than Rp. 750,000 account for 118 humans (60.5 $\%$ ), whereas respondents with a monthly income of less than Rp. 750,000 account for 77 humans (39.5\%).

The findings of descriptive statistical analysis indicate that the variable love of money (X 1) has a rating range of 22 to 50, with an common of 42.08 and a wellknown deviation of 6.06. The gender variable (X 2) has a score vary of 0 to 1 , an average of 0.67 , and a preferred deviation of 0.47 . The socioeconomic popularity variable (X 3 ) has a rating range of 1 to 2 , an common of 1.61, and a wellknown deviation of 0.49 . The ethical perception variable (Y) for accounting college students has a minimum rating of sixteen and a maximum score of 25 , with an average rating of 20.23 and a preferred deviation of 2.25 .

The validation check is performed to determine the validity of the questionnaire [13]. Validity test was once determined for every questionnaire object the usage of object analysis, which linked the rating for each and every object with the total score, which was the sum of the rankings for each and every item. The validity check was performed using Pearson's Correlation. If the magnitude fee $($ Sig. $)=0.05$, the judgment standards are reliable [13]. The significant value (Sig.) for all objects in this learn about is less than 0.05 , indicating that all announcement items on the love of cash questionnaire and accounting students' ethical attitudes are valid.

The reliability test is used to confirm the consistency of respondents' responses. If the Cronbach Alpha fee of an instrument is greater than 0.70 , the instrument's cost is deemed to be reliable [13]. Thus, it can be inferred that the love of money questionnaire and accounting students' ethical perceptions are accurate.

The normality check is used to determine whether or no longer the confounding or residual variables in a regression mannequin have a regular distribution [13]. The Kolmogorov-Smirnov Test was employed to decide normalcy in this study. On the unstandardized residual, a normality check can be executed to determine the impact of money obsession, gender, and socioeconomic level on accounting students' moral beliefs. It is discovered that the cost of Sig. (2-tailed) of 0.200 . Value of Sig. (2-tailed) is larger than 0.05 for the 
Kolmogorov-Smirnov Z statistic. This suggests that the facts distribution is generally distributed.

The multicollinearity test targets to decide whether or no longer there is a relationship between one impartial variable and any other. A desirable regression model not have a excessive correlation between the unbiased variables. Multicollinearity take a look at can be tested the use of Tolerance Value and Variance Inflation Factor (VIF). It is discovered that the VIF fee of each independent variable is much less than 10 and the tolerance fee is greater than 0.10 . The correlation fee between impartial variables can be stated to have a vulnerable correlation. Thus it can be concluded that among the impartial variables there is no correlation or there is no multicollinearity in the linear regression model.

The heteroscedasticity check objectives to check whether in the regression mannequin there is an inequality of variance from the residuals of one observation to any other commentary [14]. $\mathrm{n}$ this study, to take a look at heteroscedasticity using the Glejser test. It is determined that the magnitude value between the independent variables and the absolute residual (ABS) is increased than 0.05 . So, it can be concluded that the regression model used does now not have any symptoms of heteroscedasticity.

Multiple linear regression evaluation goals to predict modifications in the fee of certain variables if different variables change [15]. If the variance of the residual from one statement to every other is different, it is called heteroscedasticity. A true regression model is a mannequin that does not manifest heteroscedasticity. Based on the results of multiple linear regression analysis, it can be seen the equation of the regression line the use of regular evaluation and beta coefficients. The consequences of the calculation of the constants and beta coefficients as properly as the consequences of the $t$ check can be viewed in Table 1 .

Table 1. Short cut keys for the template

\begin{tabular}{|r|r|r|r|r|}
\hline \multicolumn{1}{|c|}{ Model } & Unstandardized Coefficients & Standardized Coefficients & \multicolumn{1}{c|}{ Sig } \\
\hline (Constant) & 32,588 & & 43,710 & 0,000 \\
\hline$X_{1}$ & $-0,279$ & $-0,752$ & 17,431 & 0,000 \\
\hline$X_{2}$ & 0,541 & 0,113 & 2,660 & 0,008 \\
\hline$X_{3}$ & $-0,620$ & $-0,135$ & 3,229 & 0,001 \\
\hline
\end{tabular}

Description: $\mathrm{X} 1$ = love of money, $\mathrm{X} 2$ = gender, $\mathrm{X} 3$ = socioeconomic status, and $\mathrm{Y}=$ ethical perceptions of accounting students

Based on the calculation of multiple linear regression in Table 1, the outcomes of the regression equation are as follows:

$\mathrm{Y}=+1 \mathrm{X} 1+2 \mathrm{X} 2+3 \mathrm{X} 3+$

$\mathrm{Y}=32.588-0.279 \mathrm{X} 1+0.541 \mathrm{X} 2-0.620 \mathrm{X} 3+\mathrm{e}$

Based on the regression model formed, the results can be interpreted as follows. The constant 32.588 shows if the variables $\mathrm{X} 1, \mathrm{X} 2$, and $\mathrm{X} 3$ are constant, then the $\mathrm{Y}$ variable has a positive value of 32.588 units. $\mathrm{X} 1$ has a regression coefficient of -0.279 . A negative regression coefficient value indicates that $\mathrm{X} 1$ has a negative effect on $\mathrm{Y}$. This illustrates that each increase of 1 unit of $\mathrm{X} 1$ can decrease $\mathrm{Y}$ by 0.279 assuming the other independent variables remain. $\mathrm{X} 2$ has a regression coefficient of 0.541. A negative regression coefficient value indicates that $\mathrm{X} 2$ has an effect on $\mathrm{Y}$. This illustrates that female gender is better than male in increasing $\mathrm{Y}$ by 0.541 times assuming the other independent variables remain. $\mathrm{X} 3$ has a regression coefficient of -0.620 . A negative regression coefficient value indicates that $\mathrm{X} 3$ has a negative effect on $\mathrm{Y}$. This illustrates that every 1 unit increase in $\mathrm{X} 2$ can decrease $\mathrm{Y}$ by 0.620 with the assumption that the other independent variables are constant.
The coefficient of dedication suggests how a desirable deal have an impact on the independent variable $(\mathrm{X})$ has on the dependent variable $(\mathrm{Y})$, which is indicated with the aid of the Adjusted R Square fee. In this study, the value of Adjusted R Square is used due to the fact it is encouraged to use it when evaluating which regression model is the quality [13]. It is determined that the coefficient of dedication is 0.670 . This demonstrates that sixty seven percent of accounting students' ethical perception variables are influenced by using variables associated to their love of money, gender, and socioeconomic status, whilst 33.0 percent are influenced by other variables.

The t-test is used to examine the influence of cash love, gender, and socioeconomic position on accounting students' ethical perceptions somewhat, as indicated through the magnitude of the probability price on the ttest. According to the speculation proposed in this study, and based on Table 1, the following hypotheses had been tested. Love of money (X1) has a magnitude fee of 0.000 , which is less than 0.05 and consequently rejects $\mathrm{H} 0$. Thus, it might also be argued that love of cash (X1) has a terrible affect on accounting students' ethical perceptions (Y). Gender (X2) has a magnitude degree of 0.008 , which is less than 0.05 and 
subsequently rejects $\mathrm{H} 0$. Thus, it may also be inferred that gender (X2) has an impact on accounting students' moral perceptions (Y). Socioeconomic reputation (X3) has a value stage of 0.001 , which is much less than 0.05 and hence rejects H0. Thus, it may also be argued that socioeconomic position (X3) has a poor have an effect on accounting students' ethical perceptions (Y).

\section{RESULTS \& DISCUSSION}

\subsection{The Effect of Love of Money on the Ethical Perception of Accounting Students}

The consequences of testing the first speculation involving the effect of love of money on moral perceptions of accounting college students show a regression coefficient of -0.279 with a t-test value price of 0.000 . Therefore, the first hypothesis in this find out about was accepted. This shows that love of cash has a terrible impact on moral perceptions of accounting students. The greater the love of money, the lower the ethical understanding of accounting students.

Based on the results in this learn about point out that love of money has a terrible effect on moral perceptions of accounting students. This ability that anyone who has a tendency to have a high stage of love of money has excessive unethical behavior, so love of money is used to measure how an awful lot a person's pastime in cash will have an effect on moral perceptions. The nature of the love of cash tends to encompass unethical behavior. Therefore, love of money will have a terrible effect on ethical perceptions of accounting students. The higher the level of love of money, the lower the ethical understanding of accounting college students and vice versa.

Empirical research that aid the findings of this learn about are the effects of research conducted by Aprianti [6], who determined that love of money has a sizeable impact on ethical perceptions of accounting students. In line with that, the results of Lestari's research [4] observed that love of money had a terrible effect on the ethical perceptions of accounting students

\subsection{The Effect of Gender on Accounting Students' Ethical Perceptions}

The findings confirming the second hypothesis, specifically the impact of gender on accounting students' ethical attitudes, indicate a regression coefficient of 0.541 and a t-test magnitude price of 0.008. As a result, the study's second hypothesis is accepted. This demonstrates that gender has an effect on accounting students' moral perceptions. When accounting students are female, their ethical grasp is most desirable to that of male students.

The findings of this learn about show that gender has an effect on accounting students' moral perceptions.
This suggests that the nice association between gender and accounting students' moral conceptions can be evident in the reality that men and women have distinct ethical perspectives This is because men and women differ in their ability to shape career interests, decisions, and implementation. Gender or gender identity is a cultural and social construct that has been applied to women and men. Men are more rational in their approach to difficulties and enjoy challenges, whereas women are more emotional in their approach to problems and prefer to avoid them. Women are more forceful when it comes to forming ethical judgements. As a result, it is clear that female students have a more ethical perspective when evaluating the ethical behavior of accountants. Men and women differ in their ethical judgements due to their differing moral perspectives. Due to the fact that men and women view and comprehend circumstances differently, their motivations and guiding elements in decision making will also differ.

The empirical research that support the findings of this learn about are these of Wijayanti et al., [16], which display that gender has an impact on ethical behavior. The same conclusion is drawn through Aprianti's [6] research, which suggests that gender has a considerable impact on accounting students' ethical perceptions.

\subsection{The Effects of Socioeconomic Status on Accounting Students' Ethical Perceptions}

The findings of confirming the third hypothesis, which is that socioeconomic position has an impact on accounting students' moral beliefs, point out a regression coefficient of -0.620 and a t-test magnitude cost of 0.001 . As a result, this study's $1 / 3$ speculation is accepted. This demonstrates that socioeconomic popularity has a bad affect on accounting students' ethical perceptions. The greater the socioeconomic reputation of accounting students, the less moral they are.

The findings of this study demonstrate that socioeconomic level has a negative impact on accounting students' ethical perceptions. This suggests that when one's socioeconomic level increases, one's ethical perception decreases. On the other hand, the lower one's socioeconomic standing is, the more ethically conscious one is. If an individual has a high social position, he or she is more likely to desire more money and engage in consumptive behavior. Someone with a high social rank may have a higher perceived value and be more self-interested in a social setting comprised of medium and upper social castes. According to Sipayung [10], socioeconomic status is a perspective or a measure of a person's position when it comes to social and economic factors such as occupation, income, and participation in a social association. This relates to ethical behavior, since those 
with a high socioeconomic level are more likely to act unethically.

Empirical studies that confirm the conclusions of this study including Aprianti [6]'s findings that socioeconomic position has a considerable impact on accounting students' ethical judgments. Saputri's [7] research demonstrates a similar outcome, indicating that socioeconomic background has an effect on students' ethical perceptions. In line with that, the findings of Munawaroh's research [17] point out that socioeconomic popularity has a terrible effect on accounting students' ethical perceptions.

\section{CONCLUSION}

\subsection{Conclusion}

The following conclusions can be derived from the findings of study and dialogue related to the affect of love of money, gender, and socioeconomic reputation on accounting students' moral perceptions. (1) love of cash has a bad impact on accounting students' moral perceptions, as verified via a terrible regression coefficient of -0.279 and a t-test significance degree of zero much less than $=0.05$. (2) Gender has an effect on accounting students' moral perceptions, as evidenced via a fine regression coefficient of 0.541 and a t-test importance level of 0.008 much less than $=0.05$. (3) Socioeconomic fame has a poor impact on accounting students' ethical beliefs, as evidenced by way of a terrible regression coefficient of -0.620 and a t-test magnitude price of 0.001 less than $=0.05$.

\subsection{Suggestion}

On the basis of the findings, discussion, and conclusions, the following recommendations can be made. For Ganesha University of Education, based on research findings regarding money love, gender, and socioeconomic status, it increases students' capacity for ethical behavior, implying that it is better to increase curriculum content on ethics and the benefits of money in everyday life during the learning process. Both studies found a coefficient of determination of 0.670 , indicating that 67.0 percent of the variance in accounting students' moral view is explained by variables such as love of money, gender, and socioeconomic class, while the remaining 33.0 percent is explained by way of other variables. Due to the fact that various factors affect accounting students' moral perceptions, it is recommended that future researches consist of more independent variables that probably have an effect on accounting students' moral views. The following three researchers are urged to expand the research population, namely by increasing the number of universities, not just Ganesha Education University, in order to acquire more generalizable research results.

\section{REFERENCES}

[1] A. H. Jusuf, Dasar-Dasar Akuntansi, Jilid II. Yogyakarta: STIE YKPN, 2001.

[2] E. F. Himmah, "Persepsi Etis Mahasiswa Akuntansi Mengenai Skandal Etis Auditor dan Corporate Manajer," J. Akunt. Multiparadigma, vol. 4(1 ), pp. 26-39, 2013.

[3] N. J. Mastracchio, "Teaching CPAs About Serving the Public Interest," CPA J., pp. 6-9, 2005.

[4] B. W. Lestari, "Pengaruh pengetahuan etika, religiusitas dan love of money terhadap persepsi etis Mahasiswa Akuntansi: Studi kasus pada Mahasiswa Akuntansi Universitas Islam Negeri Maulana Malik Ibrahim Malang," Universitas Islam Negeri Maulana Malik Ibrahim., 2019.

[5] A. R. Diana, "Pengaruh Pengetahuan Etika, Religiusitas Dan Love Of Money Terhadap Persepsi Etis Mahasiswa Akuntansi," $A B A J$., vol. 102(4), pp. 24-25, 2017.

[6] V. Aprianti, "Pengaruh Usia, Gender, Status Sosial Ekonomi Akuntansi dan Pengelaman Kerja terhadap Persepsi Etis Mahasiswa Akuntansi dengan Love of Money sebagai Variabel Intervening," Universitas Muhammadyah, Yogyakarta, 2016.

[7] D. E. Saputri, "Hubungan Jenis Kelamin, Pengalaman Magang, Latar Belakang Sosial Ekonomi Dan Love Of Money Dengan Persepsi Etis Mahasiswa Akuntansi," Ekon. Dan Bisnis, vol. 105(1), p. 43, 2018.

[8] R. S. N. Sari, R. Zuhdi, and N. Herawati, Tafsir Perilaku Etis Menurut Mahasiswa Akuntansi Berbasis Gender. Purwokerto: SNA XIII, 2010.

[9] N. K. A. Purnamaningsih and D. Ariyanto, "Pengaruh Gender, Usia, Tingkat Pendidikan dan Status Sosial Ekonomi Terhadap Persepsi Etis Mahasiswa Akuntansi.," E-Jurnal Akunt. Univ. Udayana, vol. 17(2), 2016.

[10] E. R. Sipayung, "Analisis Pengaruh Aspek Demografi, Status Sosial Ekonomi Dan Pengalaman Kerja Terhadap Persepsi Etis Mahasiswa Akuntansi Dengan Love of money Sebagai Variabel Intervening," Universitas Diponegoro Semarang, 2015.

[11] Z. Heru, R. Dandes, and F. Popi, "Pengaruh Religiusitas, Status Sosial Ekonomi, Dan Love Of Money Terhadap Persepsi Etis Mahasiswa Akuntansi (Studi Empiris pada Mahasiswa Akuntansi Perguruan Tinggi di Kota Padang)," Universitas Bung Hatta, 2020.

[12] Sugiyono, Statistika Untuk Penelitian. Bandung: Pustaka Setia, 2009. 
[13] I. Ghozali, Aplikasi Analisis Multivariate Dengan Program IBM SPSS 19. Semarang: Badan Penerbit Universitas Diponegoro, 2011.

[14] I. Ghozali, Aplikasi Analisis Multivariate dengan Program IBM SPSS 21: Update PLS Regresi. Semarang: Badan Penerbit Universitas Diponegoro, 2013.

[15] Sugiyono, Metode Penelitian Kombinasi (Mix Methoders). Alfabeta, 2013.

[16] D. M. Wijayanti, F. J. Kasingku, and R. Rukmana, "Dilema Etika pada Akuntan Sebuah Studi Persepsi Mahasiswa Akuntansi," J. Din. Akunt., 2017.

[17] U. K. Munawaroh, M. Maslichah, and D. Sudaryanti, "Pengaruh Religiusitas, Status Sosial Ekonomi, Love Of Money Dan Gender Terhadap Persepsi Etis Mahasiswa Akuntansi (Studi Kasus di satu PTN dan dua PTS di Malang)," J. Ilm. Ris. Akunt., vol. 9(10), 2020. 